\title{
Incineration Process for Municipal Solid Waste In Palghar District
}

\author{
Anoop Mujalge ${ }^{1}$, Elvis Rodrigues ${ }^{2}$, Nikita Patil ${ }^{3}$, Shivam Shirke ${ }^{4}$, Prof. Shreeshail B Heggond ${ }^{5}$ \\ ${ }^{1,2,3,4}$ U.G. Student, Civil Engineering Department, St. John College of Engineering \& Management Palghar, India, 401404. \\ ${ }^{5}$ Assistant Professor, Civil Engineering Department, St. John College of Engineering \& Management Palghar, India,
}

DOI: 10.46335/IJIES.2020.5.6.8

\begin{abstract}
Today one of the major problem which remains in modern societies is Municipal Solid Waste $(M S W)$, in spite of the significant efforts to prevent, reduce, reuse and recycle. In most of the developed countries at present, municipal solid waste incineration (MSWI) in waste - to - energy (WTE) plants is one of the main management options. The waste material collection is piling up every day in almost all cities in India and creating hazardous situation in terms of pollution. Palghar is a newly formed district from Thane district. Palghar district consists of Vasai, Virar, Palghar, Jawahar and Dahanu; housing a population of 13,35,316 as per Maharashtra Pollution Control Board, Annual Report 2017-18. The amount of solid waste treated in Palghar district is nil and MSW processing facility available is only dumping. Due to this the average life span of living beings has deteriorated to a great extent. Our main aim is to utilize these waste materials in an effective way to help mankind by the process of incineration. Incineration is the best process of combustion of organic materials present in the waste and giving useful by-products. The by-products of incineration are heat, flue gases and ash. The effective use of these by-products can be generation of electricity, growth in production of crops. We are attempting to assess the possible situation of the effective utilization of low cost incineration and air pollution control devices used for cleaning. Thus we propose a model for the incineration of MSW in Palghar district.
\end{abstract}

Keywords- Incineration, Municipal Solid Waste (MSW), Hazardous, Energy.

\section{I- INTRODUCTION}

$\mathbf{S}_{\mathrm{o}}$ olid waste is majorly classified into four types as
a. Municipal Solid Waste
b. Hazardous Solid Waste
c. Bio-Medical Waste
d. E-Waste

As per the data of 2017 - 18 given by Maharashtra Pollution Control Board, Total Generation and Treatment of Hazardous Waste in the State during 201718. Hazardous Waste Generation as per Consent (MT/annum)

Land fillable 725444.35

Incinerable 353286.72

Recyclable 1091514.03

Utilizable 276429.20

Indian Renewable Energy Development Agency (IREDA) estimates indicate that India has so far realized only about $2 \%$ of its waste-to-energy potential. Various technologies are available presently for the generation of energy from waste like "Thermal Conversion, Thermo Chemical Conversion, Bio - Chemical Conversion and Electro - Chemical Conversion." Waste to energy, is an alternative to disposing of waste in landfills, waste to energy generates clean, reliable energy from a renewable fuel source, reduces dependence on fossil fuels, the 
combustion of which is a major contributor to GHG emissions. This method would reduce the amount of wastes, generate a substantial quantity of energy from them, and also significantly reduce pollution of water and air. Improper management of MSW institutes/ warrants a growing concern for cities in developing nations. Proper management requires the construction and installation of essential facilities and machinery, based on a suitable management plan (Shimura, S., 2001 and Das et al., 1998).

This project deals with processing and disposing off municipal solid wastes along with the production of the fluff and Refuse Derived Fuel for power generation that can be a source of revenue also. "Waste to Energy" plants remove recyclable or unburnable materials and shred or process the remaining trash into a uniform fuel. In an RDF plant, waste is processed before burning.

Typically, the non-combustible items are removed, separating glass and metals for recycling. A dedicated combustor, or furnace, may be located on-site to burn the fuel and generate power; or the RDF may be transported off site for use as a fuel in boilers that burn other fossil fuel. Thus the waste-to-energy plants offer two important benefits of environmentally safe waste management and disposal, as well as the generation of clean electric power.

The land for the site is an abandoned site adjacent to Dahanu Reliance Thermal Power Plant. Landfill site spread over 5.728 acres with an investment over of Rs.1000.00 million (approximately 18.20 million US\$). The proposed plant at Dahanu, Palghar District is designed to process 1300 TPD (tons per day) of Municipal Solid Waste (MSW). A RDF plant based on DST-TIFAC Technology is designed to process 1300 TPD of MSW to generate around 433 TPD of RDF in the form of fluff and a power plant of $10 \mathrm{MW}$ capacity based on RDF is provided.

\section{II- METHODOLOGY}

Incineration is a waste treatment process that involves the combustion of organic substances contained in waste materials. Incineration of waste materials is converted into ash, flue gas and heat. This process is being planned to generate electricity from the Municipal Solid Waste generated in Palghar District. There are various types of incinerators out of which "Moving Grate Incinerator" is planned to use for the electricity generation. Moving grate incinerator is a typical incinerator plant for municipal solid waste. It enables the movement of waste through combustion chamber and complete combustion is done with more efficiency. A single moving grate boiler can handle up to 35 metric tons (39 short tons) of waste per hour, and can operate 8,000 hours per year with only one scheduled stop for inspection and maintenance of about one month's duration.Moving grate incinerators sometimes can be referred as Municipal Solid Waste Incinerators (MSWIs). The plant will be designed to work for two shifts per day and shall operate for 335 days in a year. There may be forced closure of plant during the short rainy days in Palghar District. Depending on many factor, the GCV of the fuel should be about $1150 \mathrm{kcal} / \mathrm{kg} \pm 100 \mathrm{kcal} / \mathrm{kg}$.

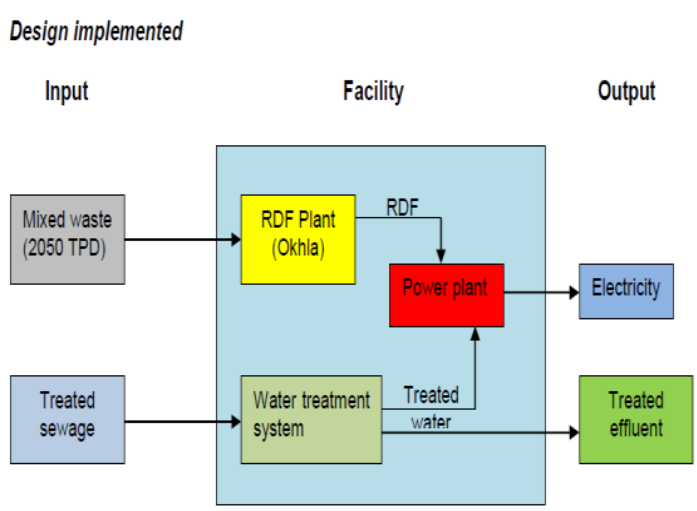

A specific environmental management system as well as proper air pollution control will be installed to ensure that all these possible emissions are within the limits as prescribed by National Ambient Air Quality Standards (NAAQS).

Considering chance emissions of dioxins and furans in future, a dioxin and furan emission control system will also be installed with injection of Activated carbon in the flue gases

\section{Measures to Control Emissions}

\begin{tabular}{|l|l|l|l|}
\hline \multicolumn{1}{|c|}{ Emission } & \multicolumn{1}{|c|}{ Source } & \multicolumn{1}{|c|}{ Major Cause } & \multicolumn{1}{c|}{ Control Mechanism/technology } \\
\hline $\begin{array}{l}\text { Carbon } \\
\text { Monoxide } \\
(C) \mid\end{array}$ & Carbon in fuel & Incomplete combustion & $\begin{array}{l}\text { Boiler and grate design to enhance combustion and } \\
\text { turbulence, auxiliary burners }\end{array}$ \\
\hline $\begin{array}{l}\text { Particulate } \\
\text { Matter (PM) }\end{array}$ & $\begin{array}{l}\text { Carbon and } \\
\text { minerals in } \\
\text { fuel }\end{array}$ & $\begin{array}{l}\text { Incomplete combustion } \\
\text { and }\end{array}$ & $\begin{array}{l}\text { Boiler and grate design to enhance combustion and } \\
\text { turbulence, auxiliary burners, fabric filters }\end{array}$ \\
\hline $\begin{array}{l}\text { Nitrogen } \\
\text { Oxides (NOx) }\end{array}$ & $\begin{array}{l}\text { Nitrogen in } \\
\text { fuel and } \\
\text { primary air }\end{array}$ & $\begin{array}{l}\text { High temperature } \\
\text { conditions }\end{array}$ & $\begin{array}{l}\text { Flue gas recirculation, selective non-catalytic } \\
\text { reduction }\end{array}$ \\
\hline $\begin{array}{l}\text { Sulfur Dioxide } \\
\text { (SO2) }\end{array}$ & Sulfur in fuel & Product of Oxidation & $\begin{array}{l}\text { Packed bed absorption with alkaline scrubbing } \\
\text { liquid }\end{array}$ \\
\hline $\begin{array}{l}\text { Hydrogen } \\
\text { Chloride (HCl) }\end{array}$ & $\begin{array}{l}\text { Chlorine in } \\
\text { fuel }\end{array}$ & Product of Halogenation, & $\begin{array}{l}\text { Dry lime injection, packed bed absorption with } \\
\text { acidic scrubbing liquid }\end{array}$ \\
\hline
\end{tabular}




\begin{tabular}{|l|l|l|l|}
\hline $\begin{array}{l}\text { Dioxins and } \\
\text { Furans }\end{array}$ & $\begin{array}{l}\text { Organic } \\
\text { chlorine in } \\
\text { fuel }\end{array}$ & $\begin{array}{l}\text { Incomplete combustion } \\
\text { and temperatures } \\
\text { between } 140-149^{\circ} \mathrm{C}\end{array}$ & $\begin{array}{l}\text { Auxiliary burners, high temperature oxidizing } \\
\text { conditions, rapid gas cooling, adsorption by } \\
\text { activated carbon injection }\end{array}$ \\
\hline Mercury (Hg) & $\begin{array}{l}\mathrm{Hg} \text { in waste } \\
\text { stream }\end{array}$ & Adsorption by activated carbon injection \\
\hline Lead (Pb) & $\begin{array}{l}\text { Pb in waste } \\
\text { stream }\end{array}$ & Fabric filters \\
\hline $\begin{array}{l}\text { Trace organic } \\
\text { compounds }\end{array}$ & $\begin{array}{l}\text { Carbon and } \\
\text { hydrogen in } \\
\text { fuel }\end{array}$ & Incomplete combustion & High temperature oxidizing conditions \\
\hline $\begin{array}{l}\text { Fugitive } \\
\text { Emissions }\end{array}$ & $\begin{array}{l}\text { Initial waste } \\
\text { handling }\end{array}$ & & $\begin{array}{l}\text { Negative pressure buildings and use as primary air } \\
\text { for combustion }\end{array}$ \\
\hline
\end{tabular}

During the activity there are more possibilities of Green House gases (GHGs) emissions. Following table shows the sources and types of GHGs evolved during Baseline and Project activity.

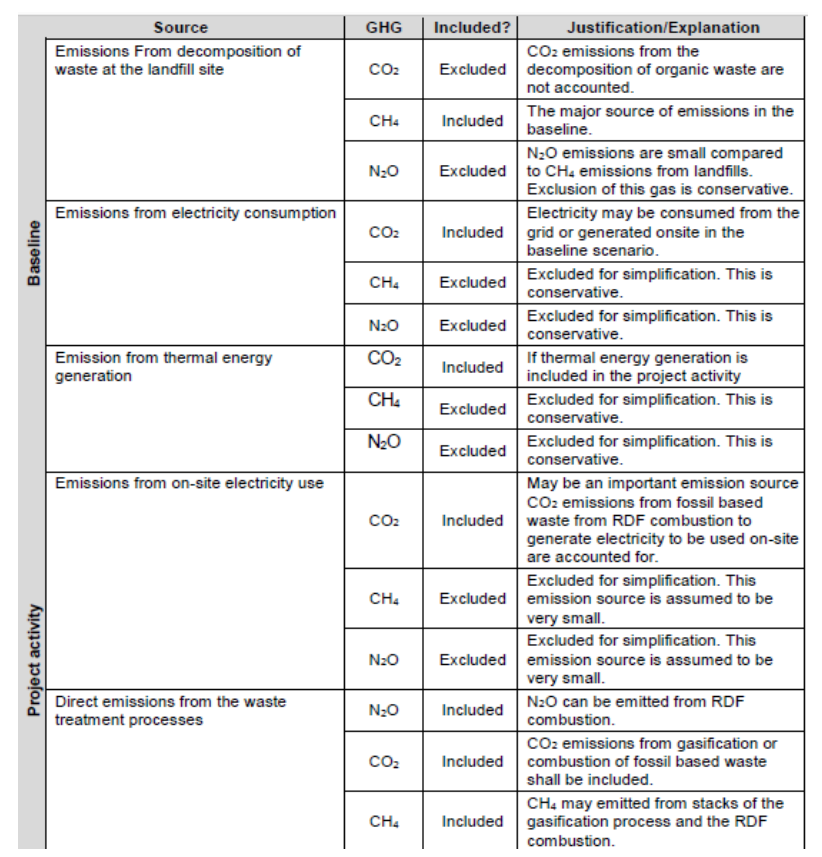

Equipments like Cyclones, Venturi Scrubbers, Electrostatic Precipitators and Fabric filters are used to control the air pollution.

The various processes takes place in the incineration plant is schematically shown below.

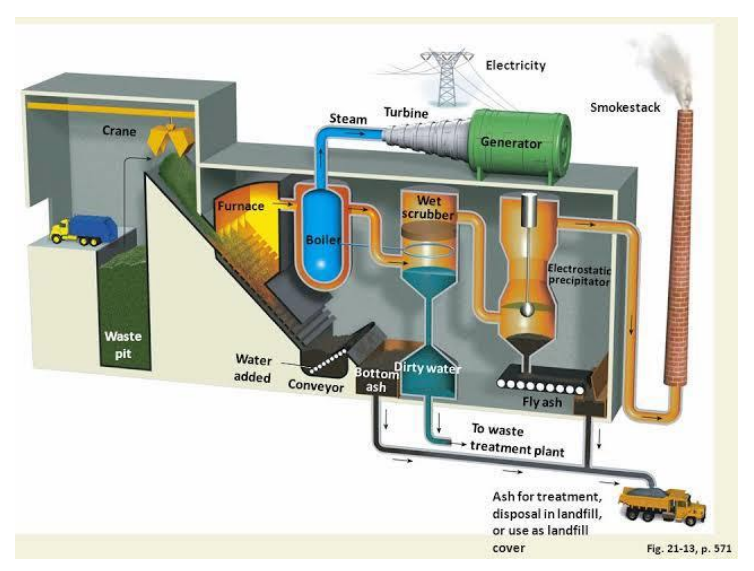

- Collection vehicles transport incinerable waste to the WTE plants. The vehicles are weighed on a weighbridge before and after they discharge their loads into large waste pit. This weighing process enables the WTE to keep track of the amount of waste disposed of by each vehicle.

- To prevent odours from escaping into the environment, the air in the waste pit is kept below atmospheric pressure.

- The waste from the waste pit is fed into the furnace by a grab crane.

- As the furnace is operated at temperatures between 850 and 1000 degree Celsius, a lining of refractory material protects the incinerator walls from the extreme heat and corrosion. After incineration, the waste is reduced to ash which is about 10 per cent of its original volume.

- In contrast to furnace, in the boiler the heat produced in furnace in the form of gases get cooled by convective heat transfer to tubes located in the flow.

- Water in the wall tubes get boiled and turns it into steam. This steam passes through turbine at high pressure and turbine drives the generator. This generator generates electricity.

- Some part of waste is incombustible, this part remains after incineration which we called as bottom ash. And high quality building materials used it; for example concrete and asphalt.

- The wet scrubber are effective air pollution control devices for removing particles and gases from streams.

- A wet scrubber operates by introducing a dirty gas stream with a scrubbing liquid - typically water.

- An efficient flue gas cleaning system comprising electrostatic precipitators, which is a filtration device that removes fine particles like dust and smoke from a flowing gas, before it is released into the atmosphere via chimney, as per government regulation and under some limits.

- And remaining fly ash is used as filling material in asphalt.

\section{III- EQUATIONS \& CALCULATIONS}

Mathematical formulas for calculating waste collection.

$$
P W G=(P B Y+P B Y \times A G P) \times(P C W B+P C W B \times
$$$$
A G W) \times 365 \times 1 / 1000
$$ 
Here,

PWG = projected wastes generation in a year (tons); (686750 MT or 2050 TPD)

PBY = population in baseline year; $(30,00,000)$

AGP = annual growth rate of population; $30 \%$

PCWB = per capita wastes generation in baseline year (kg/cap/day); (1.1 kg/cap/day)

AGW = average growth rate in the per capita waste generation $(3.7 \mathrm{~kg})$

Mathematical formulae for electricity generated by Incineration process.

Expression to Calculate the Amount of Electricity that can be obtained from Incineration

\section{$E R P i=\eta(M . L C V M S W) / 1000$}

Where,

ERPi = Energy Recovery Potential from incineration [MWh/day]. (20.9 MW)

$\mathbf{M}=$ Total mass of dry solid waste [Kg/day]. $(2050 \times 1000)$

LCVMSW = Lower Calorific Value of the Waste [kWh/Kg]. (0.04)

$\boldsymbol{\eta}=$ Total process efficiency. $(0.25)$

Financial Analysis

\begin{tabular}{|l|l|}
\hline Items & Assumptions \\
\hline Debt -Equity & $2: 1$ (66.67:33.33) \\
\hline Interest rate & $10 \%$ \\
\hline Processing Fee & $2 \%$ \\
\hline Loan Repayment Period & $5 \mathrm{Yrs}$. \\
\hline Moratorium & 1 yr \\
\hline $\begin{array}{l}\text { Infrastructure Development (Establishing } 10 \\
\text { MW Electricity Plant) }\end{array}$ & 1 Year. (2020-2021) \\
\hline Inflation & $\begin{array}{l}6 \%(2020-2025), 7 \%(2025-2030), \\
8 \%(2030-2035) \text { and } 9 \%(2035-2040)\end{array}$ \\
\hline Security Deposit period & $5 \quad 12$ months \\
\hline
\end{tabular}

Operation \& Maintenance Cost (In Million INR)

\begin{tabular}{|l|l|l|l|l|}
\hline Cost & $\begin{array}{l}\text { First 5-Years } \\
(\mathbf{2 0 2 0 - 2 0 2 5 )}\end{array}$ & $\begin{array}{l}\text { Second 5-Years } \\
(\mathbf{2 0 2 5}-2030)\end{array}$ & $\begin{array}{l}\text { Third 5-Years } \\
\text { (2030-2035) }\end{array}$ & $\begin{array}{l}\text { Last 5-Years } \\
\text { (2035-2040) }\end{array}$ \\
\hline $\begin{array}{l}\text { Operation \& } \\
\text { Maintenance }\end{array}$ & 250.00 & 360.00 & 420.00 & 560 \\
\hline
\end{tabular}

\begin{tabular}{|l|l|l|l|l|}
\hline Escalation Cost & $6 \%$ & $7 \%$ & $8 \%$ & $9 \%$ \\
\hline
\end{tabular}

Total Project Cost (In Million Indian Rupees)

\begin{tabular}{|l|l|}
\hline Items & $2020-2040$ \\
\hline Base Project Cost & 1000.00 \\
\hline 0\&MCost & 1190.00 \\
\hline TPC (Total Project Cost) & 2190.00 \\
\hline
\end{tabular}

Total Revenue (In Million Indian Rupees)

\begin{tabular}{|l|l|}
\hline Item & $2020-2040$ \\
\hline Revenue from 10MW Electricity & 10468.50 \\
\hline Revenue from Carbon Credit & 313.11 \\
\hline $\begin{array}{l}\text { Total Revenue from Electricity Generation } \\
\text { and Carbon Credit* }\end{array}$ & 10781.61 \\
\hline
\end{tabular}

Result of Debt-Equity Ratio in Million INR

\begin{tabular}{|l|l|l|l|l|l|}
\hline Year & $\begin{array}{l}\text { Yearl } \\
2020\end{array}$ & $\begin{array}{l}\text { Year } \\
2021\end{array}$ & $\begin{array}{l}\text { Year } \\
2022\end{array}$ & $\begin{array}{l}\text { Year } \\
2023\end{array}$ & $\begin{array}{l}\text { Year } \\
2024\end{array}$ \\
\hline Opening Balance & & 666.70 & 500.00 & 366.68 & 225.00 \\
\hline Loans & 666.70 & 0.00 & 33.33 & 33.33 & 33.33 \\
\hline $\begin{array}{l}\text { Interest \& processing fees } \\
\text { @12\% }\end{array}$ & 80.00 & 80.00 & 64.00 & 48.00 & 31.00 \\
\hline Principal Repayment & 0.00 & 166.68 & 166.68 & 175.01 & 183.34 \\
\hline Closing Balance & 666.70 & 500.03 & 366.68 & 225.00 & 74.99 \\
\hline Equity & 333.30 & 0.00 & 16.67 & 16.67 & 16.67 \\
\hline
\end{tabular}

\section{IV-RESULTS}

a. Total MSW Waste to be processed at the proposed Incineration Plant is $686750 \mathrm{MT}$ of waste per year@2050 TPD of MSW.

b. The Project will Sell 121.53 GWh of Electricity.

c. The Estimated Cost of the Project is Rs. 2190 Million.

d. Total Revenue form Electricity Generation and Carbon Credit Rs. 10781.61 Million

\section{V- FUTURE SCOPE}

i. In today's generation incineration is being widely used for the reduction of the volume of municipal solid waste and to produce electric energy.

ii. It reduces the toxicity of chemical and biological waste.

iii. By implementing incineration the pollution can be controlled up to some extent and certain amount of energy can be recovered.

iv. The emission rate of green houses cases i.e. $\mathrm{CH} 4, \mathrm{CO}, \mathrm{CO} 2$ and many more gases which are hazardous can be reduced.

v. If the outputs from incineration process are achieved up to the mark then the usage of fossil fuels can be reduced up to some extent.

vi. Integrated waste management can be achieved.

vii. Lesser land usage for dumping as some part of the MSW sent for the incineration which helps in the reduction of land consumption for dumping of waste. 


\section{REFERENCES}

[1] M. Habibur Rahman \& Abdullah Al-Muyeed, Solid and Hazardous Waste Management, Bangladesh, 2010.

[2] Swachh Maharashtra Abhiyan, Urban development department, Govt. of Maharashtra, Handbook of Technologies, Solid Waste Management, Maharashtra, India, 2016.

[3] A.Z.A. Saifullah, "Electrical Energy Potential from Municipal Solid Waste in Rajshahi City Corporation, Bangladesh," American Journal of Engineering Research (AJER), e-ISSN:2320-0847 p- ISSN : 23200936, Volume -4, Issue-10, pp.69-85.

[4] K.M.Nazmul Islam, "MSW to energy generation in Bangladesh: Possible scenarios to generate renewable electricity in Dhaka and Chittagong city", Hindawi publishing corporation, Journal of renewable energy, Vol.2016.

[5] Maharashtra Pollution Control Board, "Annual Report on implementation of SWM rules, 2018",

[6] Ngakan Putu Satriya Utama, Rukmi Sari Hartati, Wayan G. Ariastina, Ida Bagus A. Swamardika, Ontoseno Penangsang, "A Review on Model of Integrating Renewable Distributed Generation into Bali's Power Distribution Systems: Issues, Challenges, and Possible Solutions," Indonesian Journal of Electrical Engineering and Computer Science, Vol.4, No.2, November 2016, pp.245-255.

[7] Nidoni, Pooja G., "Incineration process for solid waste management and effective utilization of by products", IRJET, Vol:04 Issue: 12, Dec-2017, pp.378-382.

[8] R.P. Singh, V.V. Tyagi, Tanu Allen, M.Hakimi Ibrahim, Richa Kothari, "An overview for exploring the possibilities of energy generation from municipal solid waste (MSW) in Indian scenario," Renewable and Sustainable Energy Reviews, $15^{\text {th }}$ September, 2011, pp. 4797-4808.

[9] Santiago Alzate Arias., "Electricity generation potential from solid waste in three Colombian municipalities", Technologicas, Vol:21, No.42, May-August 2018, pp.111-128.

[10] Wen-Tien Tsai, "Promoting the circular economy via waste-to-power (WTP) in Taiwan", Resources, 14 May 2019. 